\title{
A Comment on "A major Change in the Stratigraphy of the Santorini Volcano in Greece"
}

\author{
Timothy H. Druitt \\ Laboratoire Magmas et Volcans, Université Clermont Auvergne-CNRS-IRD, OPGC, Clermont-Ferrand, France \\ Email: t.druitt@uca.fr
}

How to cite this paper: Druitt, T.H. (2017) A Comment on "A major Change in the Stratigraphy of the Santorini Volcano in Greece". International Journal of Geosciences, 8, 1111-1117.

https://doi.org/10.4236/ijg.2017.89063

Received: July 24, 2017

Accepted: September 16, 2017

Published: September 19, 2017

Copyright $\odot 2017$ by author and Scientific Research Publishing Inc. This work is licensed under the Creative Commons Attribution International License (CC BY 4.0).

http://creativecommons.org/licenses/by/4.0/ (c) (i) Open Access

\begin{abstract}
Friedrich and coauthors [1] propose that two prominent eruption deposits of Santorini Volcano are in fact the same unit, resulting in a major reinterpretation of the volcanic history of this caldera. Here I summarize published field and petrological evidence showing that their proposal is not correct.
\end{abstract}

\section{Keywords}

Santorini, Lower Pumice, Upper Pumice, Minoan, Caldera

\section{Introduction}

Friedrich and coauthors [1] propose that two prominent eruption deposits of Santorini Volcano are in fact a single unit. Santorini is an internationally renowned field laboratory for the study of volcanic and magmatic processes at island arc calderas. It is also a popular destination for volcanology field classes from universities all over the world. Any major revision to the eruptive history of the caldera must therefore be examined critically.

The two deposits have traditionally been referred to as the Lower Pumice Series (LPS) and Upper Pumice Series (UPS). The names late-Bronze-Age (LBA) or 'Minoan' tuff are also used for the UPS. The UPS occurs at the top of the caldera cliffs, and the LPS about half way down. Reference [1] proposes that the products of the LBA eruption were deposited on the cliff of an ancient (pre-LBA) caldera, and that this cliff had a terrace about half way down it. They envisage that the LBA products crop out today both at the top of the cliff (the UPS) and on the ancient terrace (the LPS). They deny that the LPS is the product of a distinct, earlier event, as concluded by all previous studies of Santorini. 
I do not question the existence of an ancient caldera at Santorini (probably associated with an eruption $22 \mathrm{ky}$ ago). It was proposed based on the presence of stromatolite fragments in the UPS [2], and was confirmed first by geomorphological mapping [3], then by ${ }^{36} \mathrm{Cl}$ cosmic-ray exposure dating [4], of the caldera cliffs. Evidence published to date places this ancient structure largely in the northern basin of the present-day caldera; any extension further south is as yet unconstrained.

I argue here that the authors' new interpretation is not correct, and that the UPS and LPS are the products of different eruptions. My case is based on a number of detailed studies of the UPS and LPS deposits [5]-[18], two 1:20,000 scale geological maps [7] [10], and more than $50 \mathrm{~K}-\mathrm{Ar}$ and ${ }^{40} \mathrm{Ar}-{ }^{39} \mathrm{Ar}$ radiometric dates for stratigraphically well constrained Santorini lavas and tephra [10] [19].

\section{Examination of the Evidence in Reference [1]}

Reference [1] is confusing in its terminology. While the UPS is the product of a single (LBA) eruption, the LPS has been shown to be the products of two distinct eruptions, separated by a soil [5] [7] [10] [12] [16] [17] [18]. The two deposits have been referred to as LPS1 and LPS2, or more recently as Lower Pumice 1 and Lower Pumice 2 [10]. While the authors note this, it is unclear which unit (LPS1, LPS2 or both) is envisaged to lie on the postulated cliff terrace. In what follows, I will assume that it is LPS2, which most closely resembles the UPS (pale colour, broadly silicic composition, and outcrop weathering pattern). LPS1 is completely different in appearance to the UPS (facies associations of different lithologies and colours, different lithic clast assemblages, presence of large rags of andesitic scoria; for details see [10] [16] [17]) and could not be confused with it.

Despite superficial similarities, the UPS and LPS2 are in detail quite different from each other. The plinian units of each eruption have different internal stratigraphies and contain different magmatic components. Rhyodacitic pumices and grey andesitic enclaves are present in both UPS and LPS2, but the UPS additionally contains a distinctive microphenocryst-rich andesitic pumice that is absent in the LPS2 [10] [13]. The plinian deposit of the LPS2 has a distinctive white pumice layer ('layer A2') near its base [12] [15] [18] that is absent in the UPS [8] [13]. Isopach maps for the basal plinian fall deposits of the UPS and LPS2 are completely different. The plinian deposit of the LPS2 is $25 \mathrm{~m}$ thick below Fira town and thins rapidly to $0.5 \mathrm{~m}$ near Akrotiri, giving an easterly dispersal axis; in contrast, the UPS plinian deposit is only $4 \mathrm{~m}$ thick at Fira, thins to $1 \mathrm{~m}$ at Akrotiri, and has a southeasterly dispersal [6] [8] [10] [12] [18]. The overlying base surge and low-temperature pyroclastic flow units of the LPS2 and UPS contain different facies and lithic clast assemblages [13] [18].

The main magmatic components of the UPS and LPS2 (pumiceous rhyodacites) are chemically and isotopically different [10] [12] [13] [14] [15] [18]. Rhyodacitic pumices in the UPS have bulk compositions with higher $\mathrm{SiO}_{2}$, higher 
$\mathrm{CaO}$ (at a given $\mathrm{SiO}_{2}$ content), higher $\mathrm{Ba} / \mathrm{Y}$ and $\mathrm{Ba} / \mathrm{Zr}$ ratios, and higher ${ }^{87} \mathrm{Sr} /{ }^{86} \mathrm{Sr}$ ratios than those from the LPS2 (Figure 1; see also Tables 4.4 and 6.2 of [10]). Groundmass glasses of the two units are also different [14] [15]. A diagram of $\mathrm{FeO}$ versus $\mathrm{SiO}_{2}$ serves to separate glasses from the UPS and LPS2 very clearly, enabling correlation of a pumice layer on Anafi island with LPS2, but not UPS (see Figure 7 of [15]). The LPS2rhyodacitic pumice contains accessory phenocrysts of hornblende and quartz, which are absent in that of the UPS [12]. Magnetite phenocrysts in the UPS have systematically lower $\mathrm{TiO}_{2}$ contents (and hence lower ulvospinel fractions) than those in the LPS2 (Figure 8 in [20]; Figures 11,13 and 14 in [14]), because the UPS magma was more oxidized than that of the LPS2 [14].

Field observations show that the LPS2 cannot simply be the UPS layer lying on an ancient cliff terrace. First, were the interpretation correct, then the thick sequence of layered andesitic-dactic tuffs ('Middle Tuff series' of [8]; eruptions Cape Thera to Cape Riva of [10]) visible between the UPS and LPS2 in the cliffs should stratigraphically underlie LPS2, which is inferred to be plastered onto them. It does not. The Middle Tuff units can be seen to overlie LPS2, at innumerable locations on the cliffs of southern Thera island (Figure 2). An unambiguous demonstration is afforded in the Fira quarry, where tuff extraction has created three dimensional outcrops. Second, the almost continuous presence of the LPS2 along $\sim 10 \mathrm{~km}$ of the cliffs of southern Thera would require perfect preservation of the narrow terrace proposed by the authors that would be an extraordinary coincidence. Third, both the UPS and LPS2 occur not only in the caldera cliffs, but also on the seaward coastline of Thera island, on the Akrotiri peninsula, as shown on published geological maps [7] [10]. The statements by Friedrich and coauthors [1] that the LPS units are absent in geothermal boreholes on Thera is unconvincing, since the published borehole logs group the entire very complicated sequence of pre-UPS tuffs into 'pyroclastic deposits' without detailed volcanological analysis. The LPS does not crop out at the Akrotiri
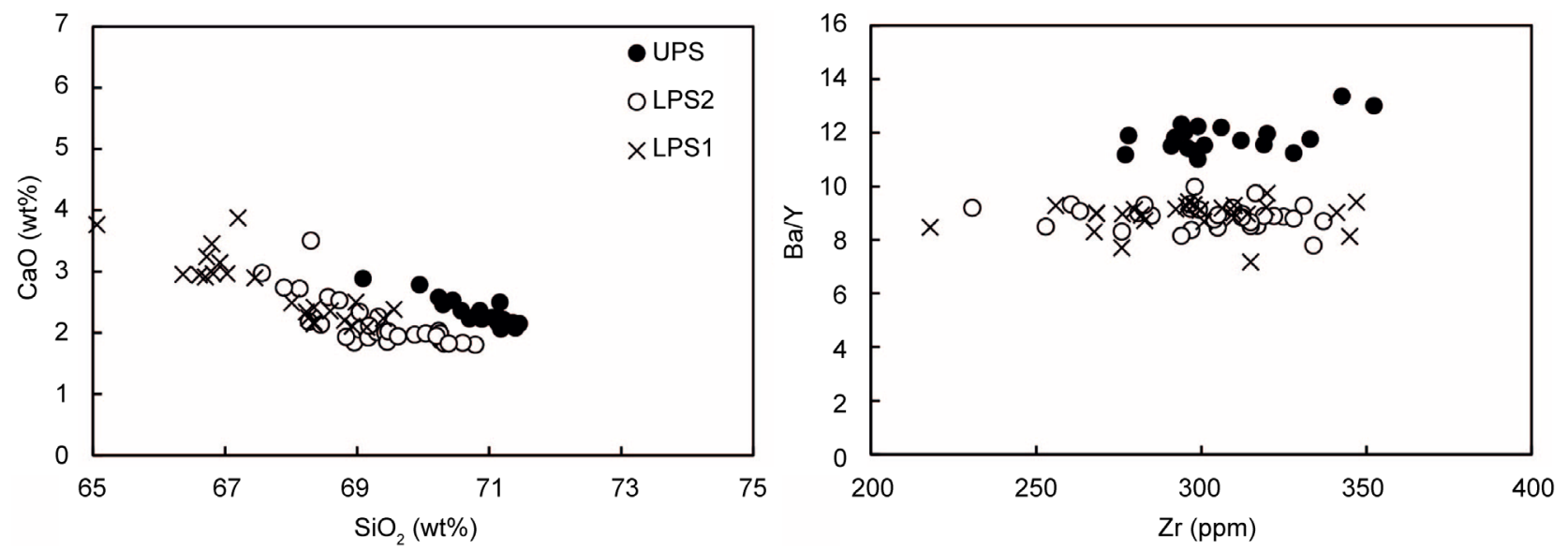

Figure 1. Bulk compositions of white pumices from the UPS and LPS2 deposits. Those from the LPS1 are included for comparison. Pumices of the UPS and LPS2 eruptions are subtly, but clearly, different in their major and trace element compositions. Data from [10] [12] [16] [18]. 


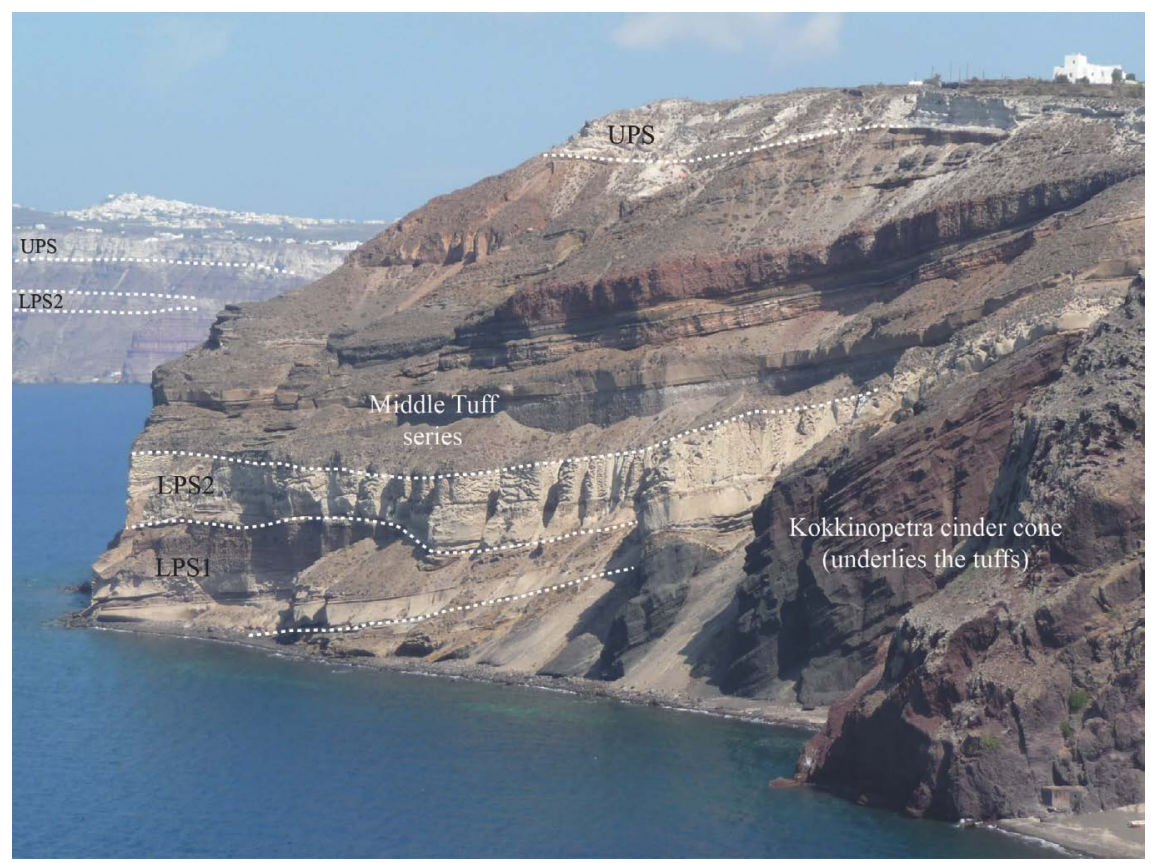

Figure 2. The cliffs of southern Thera island (Cape Loumaravi). The LPS2 is clearly not the same layer as the UPS plastered lower down the cliff surface, as proposed in [1]. It is a much older unit. Tuffs of the intervening Middle Tuff series clearly overlie the LPS2; this is especially clear at the headland, and indeed at innumerable three-dimensional outcrops all around southern Santorini. The apparent offset of the base of the LPS2 in the middle right of the photograph is due to perspective effects, not faulting.

excavation site because it is deeply buried at that location, below the tuffs of the Middle Tuff series that underlie the UPS. The only evidence provided in [1] to support the authors' statements referring to "archaeological evidence of Cycladic objects at several localities under the so-called LPS" is anecdotal. The claimed discovery of a Cycladic house some way down the caldera cliff at Balos is very interesting. If confirmed by detailed archaeological excavation, it would indeed show that that part of that cliff already existed prior to the LBA eruption. However, it does not in any way bear on the origin and age of the LPS.

The authors state that ash from the LPS2 eruption has not been found in deep-sea cores. While it is true that a correlation is not well established, the glass shard chemistry of the V-1 deep-sea ash layer in the eastern Mediterranean is consistent with correlation with the LPS2 [20] [21], which recent work places at $\sim 172 \mathrm{ka}$ ([15] and references therein). Onland chronostratigraphic constraints place the LPS2 at younger than $203 \pm 24 \mathrm{ka}$ (or younger than $224 \pm 5 \mathrm{ka}$ [K-Ar age on Cape Alonaki lavas underlying the LPS] since the authors wish to reject the previous age), but older than $172 \pm 4 \mathrm{ka}\left({ }^{40} \mathrm{Ar} /{ }^{39} \mathrm{Ar}\right.$ age on Simandiri lavas stratigraphically overlying the LPS), so the agreement is reasonable. The LPS1 is tentatively correlated with deep-sea ash V-3, which has an age of $184 \mathrm{ka}$ [15], which agrees with the $203 \pm 24 \mathrm{ka} \mathrm{K}$-Arage of the onlandLPS1 products [10]. A LPS2 origin for the V-1 ash is in fact accepted by Vinci [22], who is cited in [1] as arguing against the presence of LPS ash in the deep sea. 
Some figures in [1] show errors of field observation. The fault marked on their Figure 3 is in fact an unconformity where the Middle Tuff series pass over an ancient cliff line, probably the caldera wall of the LPS2 eruption [7] [10]. This is clear from the way in which the Middle Tuff units drape the old surface; there is no fault-related displacement of strata. This is a real example of cliff plastering, albeit a very ancient one. Their Figure 4 shows the units above and below the LPS2 (marked by the lower LBAE in the figure) as the same, labelled 'USS'. They are not the same. The lower 'USS' is a lava flow called the Cape Alonaki lava which has been dated at $224 \pm 5 \mathrm{ka} \mathrm{K}$-Ar. The upper 'USS' is the Middle Tuff series, known to span the age range from 170 to $22 \mathrm{ka}$, from K-Ar and ${ }^{40} \mathrm{Ar} /{ }^{39} \mathrm{Ar}$ dating of some units, and chemical correlation with dated deep-sea tephra for some other units (notably the $152 \pm 3$ ka Middle Pumice eruption; [23]). The term 'Upper Scoria' refers to a pair of eruptions in the Middle Tuff series [7] [10], and is not used correctly by the authors. Third, the upper layer marked LBAE in their Figure 7 is the LPS2, the middle one is the plinian fall deposit of the LPS1, and the lower one is minor dacitic unit below eruption unit Cape Therma 3 [10]. It is clear from Figure 7 of [1], and certainly in the field, that these three units cannot be the same layer plastered onto an ancient cliff surface.

\section{Conclusion}

While I agree with the authors on the existence of ancient caldera cliff surfaces and plastering relationships at Santorini, I reject the interpretation that the LPS2 was, like the UPS, laid down by the LBA eruption. The UPS (age $3.6 \mathrm{ka}$ ) and the LPS2 (best age estimate $172 \mathrm{ka}$; [15]) are the products of different eruptions, as concluded by all previous researchers who have worked in detail on the geology of Santorini. There is to date no convincing evidence that the pre-LBA caldera, which undoubtedly existed in the northern basin of the present-day caldera [2] [3] [4], extended into the southern basin.

\section{References}

[1] Friedrich, W.L., Sǿrensen, A.H., Wilson, J.R., Fytikas, M., Pavlides, S. and Katsipis, S. (2017) A Major Change in the stratigraphy of the Santorini Volcano in Greece. International Journal of Geosciences, 8, 767-780. https://doi.org/10.4236/ijg.2017.86043

[2] Eriksen, U., Friedrich, W.L., Buchardt, B., Tauber, H. and Thomsen, M.S. (1990) The Stronghyle Caldera: Geological, Palaeontological and Stable Isotope Evidence from Radiocarbon Dated Stromatolites from Santorini. In: Hardy, D.A., Ed., Thera and the Aegean World III, The Thera Foundation, London, Vol. 2, 139-150.

[3] Druitt, T.H. and Francaviglia, V. (1992) Caldera Formation on Santorini and the Physiography of the Islands in the Late Bronze Age. Bulletin of Volcanology, 54, 484-493. https://doi.org/10.1007/BF00301394

[4] Athanassas, C.D., Bourlès, D.L., Braucher, R., Druitt, T.H., Nomikou, P. and Léanni, L. (2016) Evidence from Cosmic-Ray Exposure (CRE) Dating for the Existence of a Pre-Minoan Caldera on Santorini, Greece. Bulletin of Volcanology, 78, 35. https://doi.org/10.1007/s00445-016-1026-3 
[5] Günther, V.D. and Pichler, H. (1973) The Upper and Lower Pumice Series on Santorini (Aegean Sea, Greece), NeuesJahrbuchfürGeologie und Paläontologie, 7, 394-415.

[6] Bond, A. and Sparks, R.S.J. (1976) The Minoan Eruption of Santorini, Greece. Journal of the Geological Society of London, 132, 1-16. https://doi.org/10.1144/gsigs.132.1.0001

[7] Pichler, H. and Kussmaul, S. (1980) Comments on the Geological Map of the Santorini Islands. In: Doumas, C., Ed., Thera and the Aegean World II, London, 413-427.

[8] Heiken, G. and McCoy, F. Jr. (1984) Caldera Development during the Minoan Eruption, Thira, Cyclades, Greece. Journal of Geophysical Research, 89, 8441-8462. https://doi.org/10.1029/JB089iB10p08441

[9] Druitt, T.H., Mellors, R.A., Pyle, D.M. and Sparks, R.S.J. (1989) Explosive Volcanism on Santorini, Greece. Geological Magazine, 126, 95-126. https://doi.org/10.1017/S0016756800006270

[10] Druitt, T.H., Edwards, L., Mellors, R., Pyle, D.M., Sparks, R.S.J., Lanphere, M., Davies, M. and Barriero, B. (1999) Santorini Volcano. Geological Society of London Memoir, 19, $165 \mathrm{p}$.

[11] Sparks, R.S.J. and Wilson, C.J.N (1990) The Minoan Deposits: A Review of Their Characteristics and Interpretation. In: Hardy, D.A., Ed., Thera and the Aegean World III, Thera Foundation, London, Vol. 2, 89-99.

[12] Gertisser, R., Preece, K. and Keller, J. (2009) The Plinian Lower Pumice 2 Eruption, Santorini, Greece: Magma Evolution and Volatile Behaviour. Journal of Volcanology and Geothermal Research, 186, 387-406.

[13] Druitt, T.H. (2014) New Insights into the Initiation and Venting of the Bronze-Age Eruption of Santorini (Greece), from Component Analysis. Bulletin of Volcanology, 76, 794. https://doi.org/10.1007/s00445-014-0794-x

[14] Cadoux, A., Scaillet, B., Druitt, T.H. and Deloule, E. (2014) Magma Storage Conditions of Large Plinian Eruptions of Santorini Volcano (Greece). Journal of Petrology, 55, 1129-1171. https://doi.org/10.1093/petrology/egu021

[15] Keller, J., Gertisser, R., Reusser, E. and Dietrich, V. (2014) Pumice Deposits of the Santorini Lower Pumice 2 Eruption on Anafi Island, Greece: Indications for a Plinian Event of Exceptional Magnitude. Journal of Volcanology and Geothermal Research, 278-279, 120-128.

[16] Simmons, J.M., Cas, R.A.F., Druitt, T.H. and Folkes, C.B. (2016) Complex Variations during a Caldera-Forming Plinian Eruption, Including Precursor Deposits, Thick Pumice Fallout, Co-Ignimbrite Breccias and Climactic Lag Breccias: The 184 ka Lower Pumice 1 Eruption Sequence, Santorini, Greece. Journal of Volcanology and Geothermal Research, 324, 200-219.

[17] Simmons, J.M., Carey, R.J., Cas, R.A.F. and Druitt, T.H. (2017) High Magma Decompression Rates at the Peak of a Violent Caldera-Forming Eruption (Lower Pumice 1 Eruption, Santorini, Greece). Bulletin of Volcanology, 79, 42. https://doi.org/10.1007/s00445-017-1120-1

[18] Simmons, J.M., Cas, R.A.F., Druitt, T.H. and Carey, R.J. (2017) The Initiation and Development of a Caldera-Forming Plinian Eruption (172ka Lower Pumice 2 Eruption, Santorini, Greece). Journal of Volcanology and Geothermal Research, 341, 332-350.

[19] Fabbro, G.N., Druitt, T.H. and Scaillet, S. (2013) Evolution of the Crustal Magma 
Plumbing System during the Build-Up to the 22-ka Caldera-Forming Eruption of Santorini (Greece). Bulletin of Volcanology, 75, 767.

https://doi.org/10.1007/s00445-013-0767-5

[20] Keller, J. (1981) Quaternary Tephrochronology in the Mediterranean Region. In: Self, S. and Sparks, R.S.J., Eds., Tephra Studies, D. Riedel, 227-244.

https://doi.org/10.1007/978-94-009-8537-7_14

[21] Keller, J., Ryan, W.B., Ninkovich, D. and Altherr, R. (1978) Explosive Volcanic Activity in the Mediterranean over the Past 200,000 yr as Recorded in Deep-Sea Sediments. Geological Society of America Bulletin, 89, 591-604. https://doi.org/10.1130/0016-7606(1978)89<591:EVAITM>2.0.CO;2

[22] Vinci, A. (1985) Distribution and Chemical Composition of Tephra Layers from Eastern Mediterranean Abyssal Sediments. Marine Geology, 64, 143-155.

[23] Satow, C., Tomlinson, E.L., Grant, K.M., Albert, P.G., Smith, V.C., Manning, C.J., Ottolini, L., Wulf, S., Rohling, E.J., Lowe, J.J., Blockley, S.P.E. and Menzies, M.A. (2015) A New Contribution to the Late Quaternary Tephrostratigraphy of the Mediterranean: Aegean Sea Core LC21. Quaternary Science Reviews, 117, 96-112.

Submit or recommend next manuscript to SCIRP and we will provide best service for you:

Accepting pre-submission inquiries through Email, Facebook, LinkedIn, Twitter, etc. A wide selection of journals (inclusive of 9 subjects, more than 200 journals)

Providing 24-hour high-quality service

User-friendly online submission system

Fair and swift peer-review system

Efficient typesetting and proofreading procedure

Display of the result of downloads and visits, as well as the number of cited articles

Maximum dissemination of your research work

Submit your manuscript at: http://papersubmission.scirp.org/

Or contactijg@scirp.org 